\title{
Value of color Doppler ultrasonography and radiography for the assessment of the cancellous bone scaffold coated with nano-hydroxyapatite in repair of radial bone in rabbit $^{1}$
}

\author{
Valor da ultrassonografia Doppler em cores e da radiografia na avaliação da capacidade osteo- \\ regenerativa da nano-hidroxiapatita no reparo de osso radial em coelho
}

\author{
Rasoul Rahimzadeh ${ }^{\mathrm{I}}$, Abbas Veshkini ${ }^{\mathrm{II}}$, Davood Sharifi"II, Saeed Hesaraki ${ }^{\mathrm{IV}}$ \\ 'Fellow PhD degree, Department of Clinical Sciences, Faculty of Veterinary Medicine, \\ Sanandaj Branch, Islamic Azad University, Sanandaj, Iran. Main author. Responsible for the intellectual and scientific content of the study; acquisition, \\ analysis and interpretation of data; manuscript writing \\ IIDVR, Associate Professor, Department of Radiology, Faculty of Veterinary Science, Science and \\ Research Branch, Islamic Azad University, Tehran, Iran. Acquisition and interpretation of data, ultrasonographical and radiological examinations, \\ critical revision. \\ IIIPhD, Full Professor, Department of Surgery, Faculty of Veterinary Science, Science and \\ Research Branch, Islamic Azad University, Tehran, Iran. Supervised all phases of the study and critical revision, provided guidelines for the surgical \\ interventions. \\ ${ }^{\text {IV }} \mathrm{PhD}$, Assistant Professor, Department of Materials, Energy and Materials Research Institute, Karaj, Iran. Advisor, involved in surgical interventions.
}

\begin{abstract}
PURPOSE: To evaluate the osteo-regenerative capacity of proprietary bone grafting material as a bone defect filler and osteogenetic stimulation to speed up bone healing too.

METHODS: Eighteen adult male New Zealand white rabbits were anesthetized and a segmental full thickness bone defect of 10 mm in length was created in the middle of the right radial shaft in all rabbits. They were divided into two groups of 9 rabbits. Group I was considered as control and the fractured site was fixed using finger bone plate with 4 screws, whereas the cancellous bone scaffold coated with Nano-Hydroxyapatite was used to fill the gap after fracture fixation in Group II. Radiography, two dimensional and color Doppler ultrasonography were done before and after creating defects and on 0, 15, 30, 60 and 90 days to evaluate local reaction as far as new blood vessels network and callus formation are observed.
\end{abstract}

RESULTS: On the radiographs during the whole process, bone repair in Group I was not as perfect as those in Group II samples and trace of internal callus filled the gap incompletely in 60 days in Group I, whereas in Group II internal callus almost was formed on 30 days and in addition intercortical callus was seen supporting to cover and filled the gap completely in this group in 60 day; Sonographic findings confirmed the protrusion of newly formed blood vascular network in 30 days in Group I and from 15 days in Group II and remarkably increased till end of observation period.

CONCLUSIONS: The nano-hydroxyapatite with more features and shorter in time, made possible the reconstruction of bone tissue and alternative techniques as well as previous bone graft, also radiography and ultrasonography are reliable techniques to trace local reaction at proper time.

Key words: Hydroxyapatites. Radiography. Ultrasonography, Doppler Color. Rabbits.

\section{RESUMO}

OBJETIVO: Avaliar a capacidade osteo-regenerativa de biomaterial no preenchimento de defeito ósseo e como estímulo osteogênico para acelerar a cicatrização óssea.

MÉTODOS: Dezoito coelhos brancos, Nova Zelandia, adultos, machos foram anestesiados e um defeito ósseo segmentar de toda a espessura e $10 \mathrm{~mm}$ de comprimento foi criado no meio do eixo do osso radial direito de todos os coelhos. Os animais foram distribuídos 
em dois grupos de nove: Grupo I foi considerado como controle e o local da fratura foi fixado usando placa de dedo de osso com quatro parafusos, enquanto o molde de osso esponjoso revestido com nano-hidroxiapatita foi usado para preencher o espaço após fixação da fratura no Grupo II. Radiografia, bidimensional e ultrassonografia Doppler colorida foi feita antes e após criar os defeitos e nos dias 0 , 15, 30, 60 e 90 para avaliar a reação local tais como nova rede vascular e formação do calo ósseo.

RESULTADOS: Nas radiografias durante todo o processo, o reparo ósseo no Grupo I não foi perfeito como no Grupo II; amostras e traços de calo ósseo preencheram o espaço de forma incompleta em 60 dias no Grupo I, enquanto no Grupo II o calo ósseo interno foi quase formado em 30 dias e, além disso, calo intercortical foi visto apoiar para revestir e preencher o espaço completamente em 60 dias; nos achados ultrassonográficos a protrusão da rede vascular neoformada em 30 dias no Grupo I e a partir de 15 dias no Grupo II e acentuado aumento até o fim do período de observação.

CONCLUSÕES: A nano-hidroxiapatita, com mais propriedade e menor período de tempo, tornou possível a reconstrução de tecido ósseo e técnicas alternativas como o enxerto ósseo prévio, assim como a radiografia e a ultrassonografia são técnicas confiáveis para traçar a reação local em tempo adequado.

Descritores: Hidroxiapatitas. Radiografia. Ultrassonografia Doppler em Cores. Coelhos.

\section{Introduction}

One of the clinical problems in humans and animals are healing fractures, considering the non healing hypothesis and long term healings many investigations have been performed about the case in recent decades. The main attempts of these investigations were precipitation in healings, osteopathy and battening capability. All kinds of osteografts assimilate in body and assimilation processes in spongy bones are faster than compact bones ${ }^{1-3}$. Bone can usually heal itself, but in traumatic cases, like cancer or a crushed limb, there's often an extensive amount of damage. The cancellous bone scaffold would help in these situations by bridging the missing area until new bone could grow to replace it ${ }^{4}$. In the application of bone defect repairing material, it is desired that the structure be simulated, imitated, or replicate the porous structure of biological bone, so that it can adapt to the stress changes in a certain range, circulate blood well, ensure normal growth and metabolism of bone tissue, and accelerate bone reconstruction ${ }^{5}$. Nano-hydroxyapatite (nano-HA) materials show similar chemistry to the bone apatite and depending on the underlying topography and the method of preparation, the nano-HA may simulate the specific arrangement of the crystals in bone. Hydroxyapatite (HA) and other calcium phosphate materials have been indicated in cases in which the optimal surgical fit is not achievable during surgery, and the HA surface properties may enhance bone filling of the defect $\operatorname{area}^{6}$. The biological properties of the synthetic hydroxyapatite are well documented in literature, and it has been used for correcting bone defects in human beings and in other species? ${ }^{7}$. With results good enough for indicating it as an alternative for bone graft in clinical practice. The normal healing process of fractured bones can be visualized using power Doppler ultrasonography and radiography and follows a distinctive time-dependent pattern. This investigation evaluates the cancellous bone scaffold coated with nano-HA using ultrasonographic and radiographic techniques.

\section{Methods}

This study was performed in accordance with the Islamic Azad University Law on animal experimentation. Rabbits were treated accordingly to animal welfare legal regulations. Eighteen adult male New Zealand rabbits having body weight from ranged from 3.0 - $3.5 \mathrm{Kg}$ were given general anesthesia using combinations of acepromazine $1 \mathrm{mg} \mathrm{kgbw}^{-1}$ intramuscularly as premedication (Karon Co. Iran) and anesthesia was induced intramuscularly using ketamine $35 \mathrm{mg} \mathrm{Kg}^{-1}$ (Alfasan Woerden- Holland) with combination of xylazine $5 \mathrm{mg} \mathrm{Kg}^{-1}$ (Afasan Woerden-Holland). Under restrict aseptic condition, skin incision was given on the latero medial surface of right radial bone and after separation of connective tissues and fascia a segmental full thickness bone defect of $10 \mathrm{~mm}$ in length was created in the middle of the right radial shaft in all rabbits (Figure 1). They were divided into two groups of 9 rabbits each. Group I was considered as control and the fractured site was fixed using finger bone plate with 4 screws, whereas the cancellous bone scaffold coated with NanoHydroxyapatite was used to fill the gap after fracture fixation in Group II (Figure 2). Radiography and two dimensional and color Doppler ultrasonography were done before experiment, after fixation and on 15, 30, 60 and 90 days and interpretation were done by considering dislocation of graft, new-bone formation and new blood vascular network formation. 


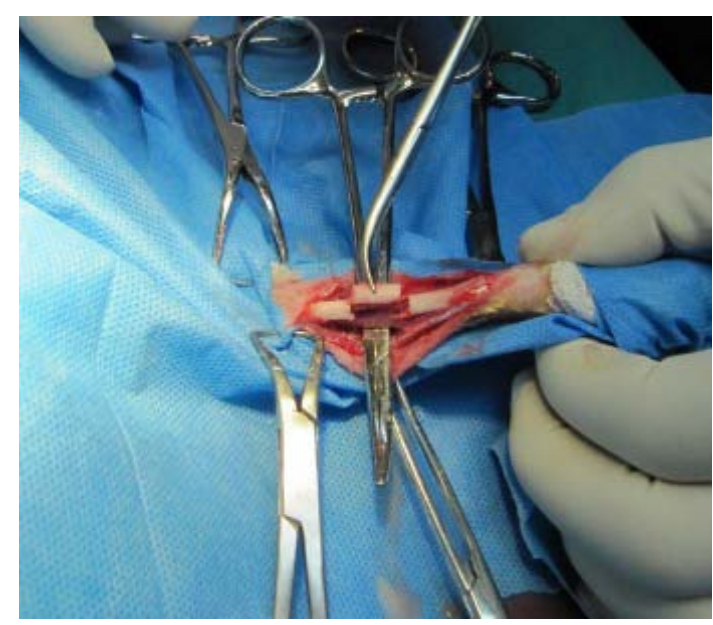

FIGURE 1 - Removal of cut piece of bone.

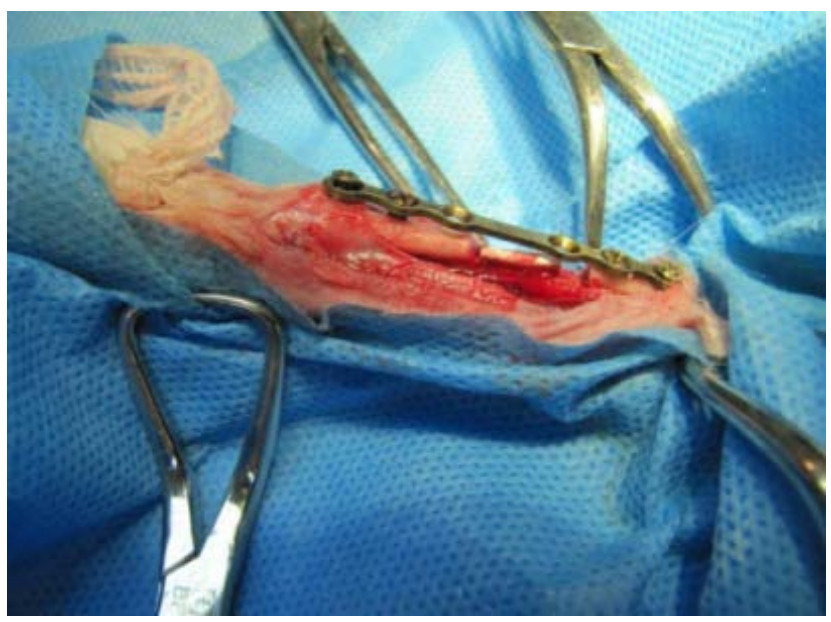

FIGURE 2 - Fixation of radial bone and packing of detect using cancellous bone scaffold coated with nano-HA.

\section{Post-operative care}

Antibiotics, penicillin $\mathrm{G}$ procaine $40000 \mathrm{IU} \mathrm{kg} \mathrm{kg}^{-1}$, I.M. bid dexamethasone $0.6 \mathrm{mg} \mathrm{Kg}^{-1}$, Vitamin B Complex $0.2 \mathrm{mg} \mathrm{Kg}{ }^{-1}$ and analgesic agent such as Tramadol hydrochloride $5 \mathrm{mg} \mathrm{Kg}^{-1}$, i.m. bid were administered for 3 post-operative days. The lateral and cranio-caudal radiographs were taken before experiment, after fixation and on 15, 30, 60 and 90 days:

- Radiographic evaluation was done using the healing indices such as:

- The probable inchoate internal callus

- The probable inchoate external callus

- The probable inchoate intercortical callus

- Osteo inductions in adjacent bones

- The amount of scaffold opacity in defective bone and its role in osteoconductivity during healings process
- The amount of healing callus in defective bones

- Sonographic evaluations were performed by Sonosite Titan Equipment. Linear probe in 10 Megahertz frequency and imbuing topical gel used in ultrasonography.

\section{Results}

No operative or postoperative complications were encountered. All of the rabbits tolerated operation well and survived until the final study period. No wound opening or infections were observed. Radiographyically keeping in view the parameters were used to evaluate the major changes revealed no sign of infection on the edges of each defect and both groups permitted stabilization of the defected bones and maintenance of correct position. The new bone formation and local reaction in form of biodegradation of cancellous bone scaffold coated with Nano-HA in the bone defects in Group II could be clearly reflected by the gradually replacing with new bone invasion. On the radiographs during the whole process, bone repair in Group I (Figure 3, Table 1) was not as perfect as those in Group II samples and trace of internal callus filled the gap incompletely in 90 days in Group I, whereas in Group II internal callus almost was formed on 30 days and in addition intercortical callus was seen supporting to cover and filled the gap completely in this group (Figure 4, Table 2) Radiographs obtained in the experimental group showed that the radiopacity of scaffold used in gap was non-uniform but so that non-uniformity in the three months after surgery decreased gradually. Ultrasonographic findings confirmed the protrusion of newly formed blood vascular network in 30 days in Group I (Figure 5, Table 3) and from 15 days in Group II and remarkably increased till end of observation period (Figure 6, Table 4). No Doppler signal was present during the first 15 days. The mean of the scores was highest between 20 and 30 days postoperatively and the median of the scores peaked between 31 and 40 days. 
TABLE 1 - Radiographic findings in Group I at different intervals.

\begin{tabular}{|c|c|c|c|c|c|}
\hline Day & $\mathbf{0}$ & 15 & 30 & 60 & 90 \\
\hline Soft Tissue & Swelling Soft Tissue & $\begin{array}{c}\text { Decrease of Swelling } \\
\text { Soft Tissue }\end{array}$ & $\begin{array}{c}\text { No Swelling Soft } \\
\text { Tissue }\end{array}$ & $\begin{array}{c}\text { No Swelling Soft } \\
\text { Tissue }\end{array}$ & $\begin{array}{c}\text { No Swelling Soft } \\
\text { Tissue }\end{array}$ \\
\hline \multirow{5}{*}{$\begin{array}{c}\text { Osseous } \\
\text { Tissue }\end{array}$} & 1.No Internal callus & 1.No Internal callus & 1. No Internal callus & 1. Internal callus & 1. Internal callus \\
\hline & 2.No External Callus & 2.No External callus & 2.No External callus & 2.No External callus & 2.No External callus \\
\hline & $\begin{array}{l}\text { 3. No cortical } \\
\text { callus }\end{array}$ & $\begin{array}{l}\text { 3.No InterCortical } \\
\text { callus }\end{array}$ & $\begin{array}{l}\text { 3.No InterCortical } \\
\text { callus }\end{array}$ & $\begin{array}{l}\text { 3.No InterCortical } \\
\text { callus }\end{array}$ & $\begin{array}{l}\text { 3. InterCortical } \\
\text { callus }\end{array}$ \\
\hline & $\begin{array}{l}\text { 4. To empty defect } \\
\text { from callus }\end{array}$ & $\begin{array}{l}\text { 4. To empty defect } \\
\text { from callus }\end{array}$ & $\begin{array}{l}\text { 4. To empty defect } \\
\text { from callus }\end{array}$ & $\begin{array}{l}\text { 4. Relative to fill } \\
\text { defect from callus }\end{array}$ & $\begin{array}{l}\text { 4. Relative to fill } \\
\text { defect from callus }\end{array}$ \\
\hline & 5.No osteo Induction & 5.No osteo Induction & 5.No osteo Induction & 5.No osteo Induction & 5.No osteo Induction \\
\hline
\end{tabular}

TABLE 2 - Radiographic findings in Group II at different intervals.

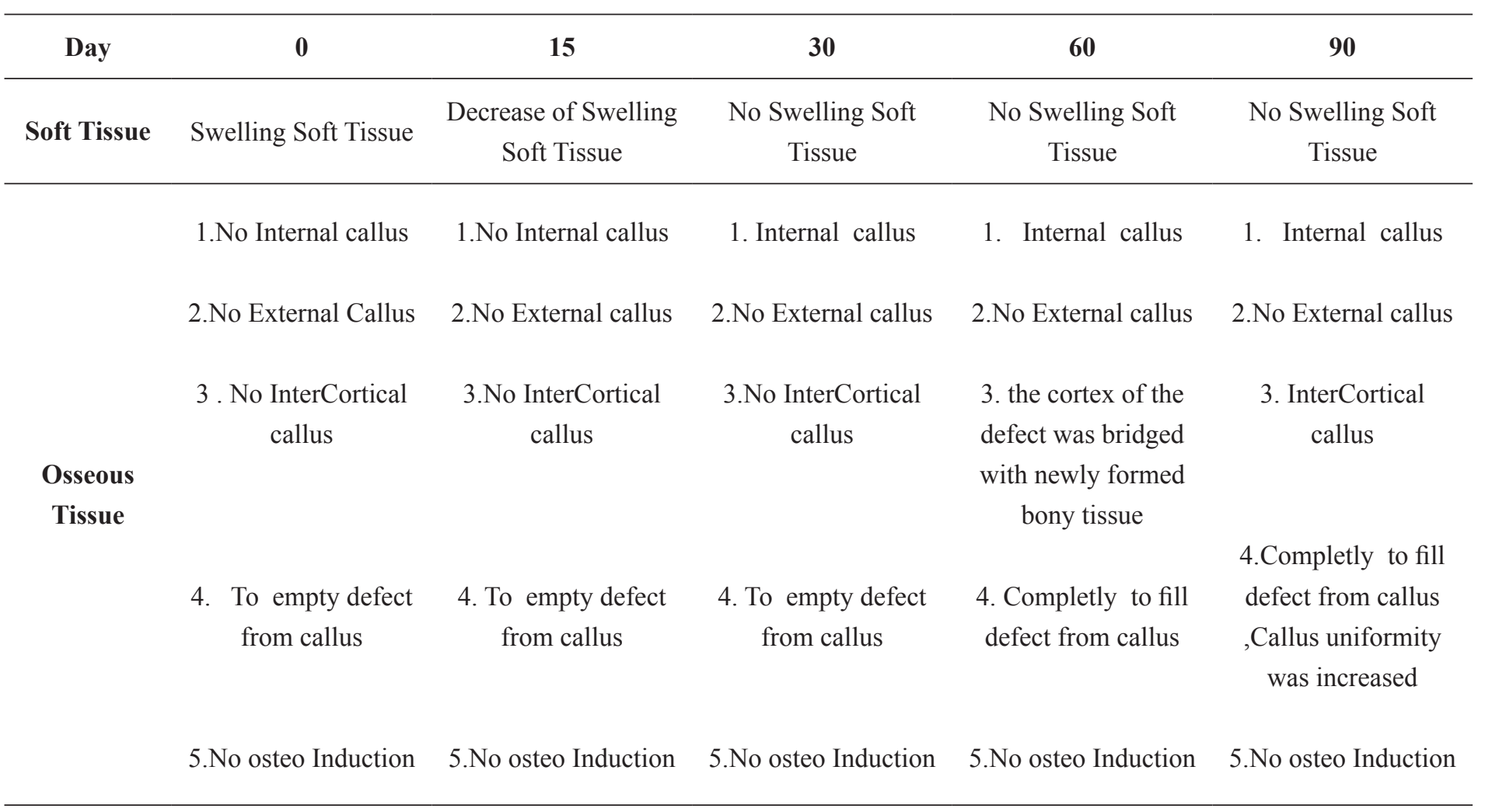


Rahimzadeh R et al.

TABLE 3 - Findings of two dimensional sonography and color Doppler in Group I.

\begin{tabular}{|c|c|c|c|c|c|}
\hline Day & 0 & 15 & 30 & 60 & 90 \\
\hline $\begin{array}{c}\text { Ultrasonography } \\
\text { B-mode } \\
\text { Oseous Tissue }\end{array}$ & $\begin{array}{l}\text { Defect : Hypo } \\
\text { Echogenicity }\end{array}$ & $\begin{array}{l}\text { Defect : Hypo } \\
\text { Echogenicity }\end{array}$ & $\begin{array}{c}\text { Defect : Increase } \\
\text { Echogenicity }\end{array}$ & $\begin{array}{c}\text { Defect : Increase } \\
\text { Echogenicity }\end{array}$ & $\begin{array}{c}\text { Defect : Increase } \\
\text { Echogenicity }\end{array}$ \\
\hline $\begin{array}{l}\text { Ultrasonography } \\
\text { Color Doppler }\end{array}$ & $\begin{array}{c}\text { Defect : No Vascular } \\
\text { Blood }\end{array}$ & $\begin{array}{c}\text { Defect : No } \\
\text { Vascular Blood }\end{array}$ & $\begin{array}{l}\text { Defect: small } \\
\text { Vascular Blood }\end{array}$ & $\begin{array}{l}\text { Defect: Many } \\
\text { Vascular Blood }\end{array}$ & $\begin{array}{l}\text { Defect : decrease } \\
\text { Vascular Blood }\end{array}$ \\
\hline
\end{tabular}

TABLE 4 - Findings of two dimensional sonography and color Doppler in Group II.

\begin{tabular}{cccccc}
\hline Day & $\mathbf{0}$ & $\mathbf{1 5}$ & $\mathbf{3 0}$ & $\mathbf{6 0}$ & $\mathbf{9 0}$ \\
\hline $\begin{array}{c}\text { Ultrasonography } \\
\text { B-mode }\end{array}$ & $\begin{array}{c}\text { Defect : Hypo } \\
\text { Oseous Tissue }\end{array}$ & $\begin{array}{c}\text { Defect : Increase } \\
\text { Echonicity }\end{array}$ & $\begin{array}{c}\text { Defect : Increase } \\
\text { Echogenicity }\end{array}$ & $\begin{array}{c}\text { Defect:Hyper } \\
\text { Echogenicity }\end{array}$ & $\begin{array}{c}\text { Defect:Hyper } \\
\text { Echogenicity }\end{array}$ \\
\hline $\begin{array}{c}\text { Ultrasonography } \\
\text { Color Doppler }\end{array}$ & Defect : No & Defect : Small & Defect: Many & Defect: Decrease & Defect : Small \\
& Vascular Blood & Vascular Blood & Vascular Blood & Vascular Blood & Vascular Blood
\end{tabular}

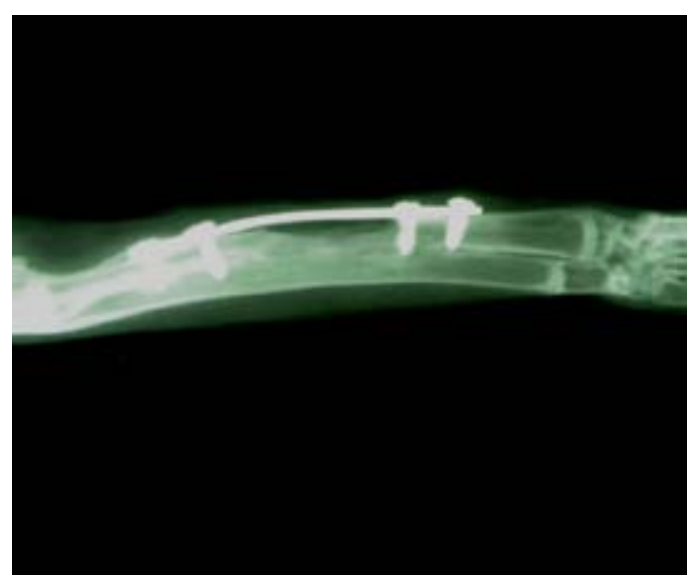

FIGURE 3 - Radiograph of group I at 90 days.

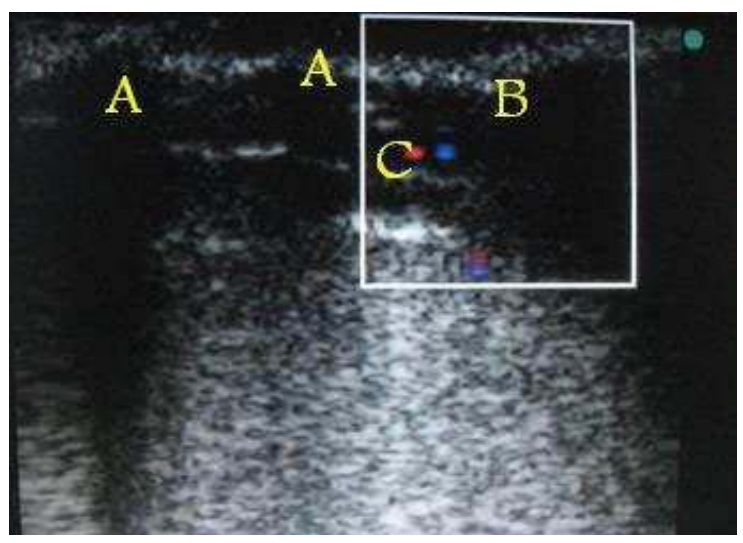

FIGURE 5 - Sonogram of group I showing: (A) Screw, (B) Defect, (C) blood vessels.

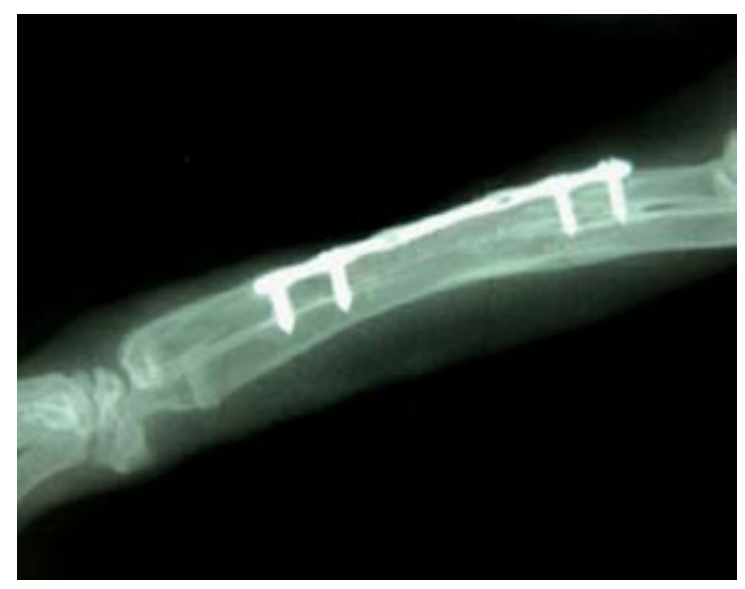

FIGURE 4 - Radiograph of group II at 90.

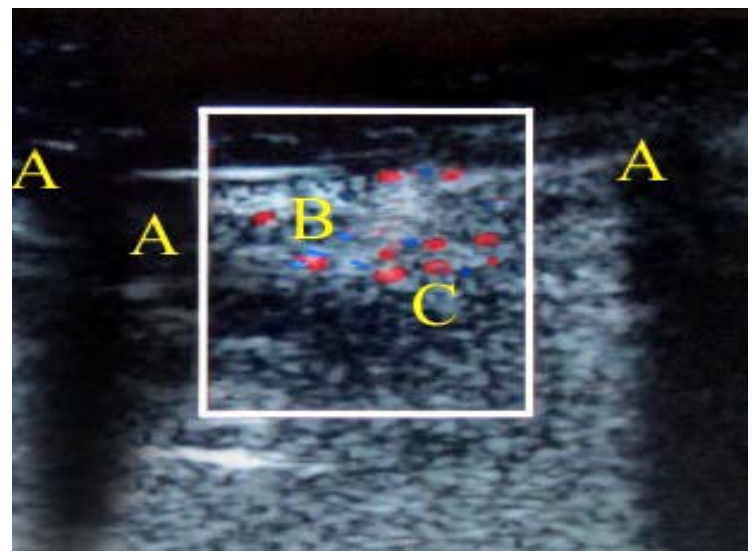

FIGURE 6 - Sonogram of group II showing:

(A) Screw, (B) Defect, (C) blood vessels. 


\section{Discussion}

Radiology is a most important diagnostic test in the investigation of skeletal disease because good radiographic contrast is naturally provided between the bone and surrounding soft tissues permitted detection of rather small but clinically important changes. Ultrasonography and the Doppler effect are noninvasive and inexpensive method of investigation, they are full of prospect for the monitoring of bone healing after fracture. The nano-HA is similar to the mineral part of natural bone in both composition and structure ${ }^{8}$. It can simulate the metabolism of nature bone and is good for new bone formation. The features of the nano-HA provid ideal frame to guide the new bone formation, so it promotes the reparative process of bone defect. As per expected no local reaction was seen during first two weeks in both groups but sonographically sprouting small blood vessels network at end of two weeks in Group II, as reported by Williamson et al. ${ }^{9}$ Hamanishi et al. ${ }^{10}$ and Tikku et al. ${ }^{11}$ With radiographic findings of intercortical callus formation within 60 days were good indication for local reaction of cancellous bone scaffold coated with nano-HA to act as stimulator to provide suitable bed for blood vessels penetration as compared to Group I. The status of bone, the vascularity, callus formation and viability of bone is a very important factor, in assessing the successful outcome of various surgical procedures. This information is not offered by routine radiographs, which cannot detect bony changes before 4 weeks. Ultrasonography is a reliable alternative, to study the callus formation. Early stages are seen as hypoechoic areas with flecks of calcification seen as hyperechoic structures ${ }^{12}$. Critical evaluation of radiographs taken at different intervals in the animals of group I revealed moderate evidence of fracture union as compared to the other group. However, in the initial stages, minimal internal callus and smoothing edges of the cortical bone defects were noticed. This may be due to the larger defect size, which is in agreement with the observations of Nandi et al. ${ }^{13}$ In the animals of group II, day 0 radiographs revealed the presence of well-placed cancellous bone scaffold in the mid-shaft radial diaphyseal defects which were relatively distinguishable to the radio-density of host bone Between days 15 to 30, there were well-established Internal callus without any signs of scaffold resorption. On day 30 , the cancellous bone scaffold were in the process of resorption from all four corners and the it were replaced by radiologically-detectable newly grown bone, which is in agreement with other observations ${ }^{13}$. On day 60, the cortex of the defect along the longitudinal axis was bridged with newly formed bony tissue, indicating a well-organized healing process. Complete bridging of the cortical defect was observed on day 90 with similar radio-dense bony material and the scaffold was encapsulated. Evaluation of ultrasonographic results of the present study revealed varying degrees of vascularization. However, the evidence of vascularization was more pronounced in animals implanted with cancellous bone scaffold coated with nano-HA than the controls. The minute vessels of periosteal and endosteal origin invading the implant bed supports the view that vascularization in fracture healing is directly related to the amount of new bone formation ${ }^{14,15}$. Findings of this study confirmed biological activity of scaffold despite of having self-blood vessels limitation. considering that bone is a natural nanostructure so it seems cancellous bone scaffold coated with nano-HA fill the deficit of local reaction to be effective.

\section{Conclusion}

Because the cancellous bone scaffold coated with nanoHA mimics bone so closely, it not only replaces the missing section of bone, but promoted bone formation over the defect, conforming their biological osteoconductive property and radiography and ultrasonography are reliable techniques to trace local reaction at proper time.

\section{References}

1. Davies JE. Mechanisms of endosseous integration. Int J Prosthodont. 1998;11(5):391-401.

2. Remedios A. Bone and bone healing. Vet Clin North Am Small Anim Pract. 1999;29:1029-44.

3. Salgado AJ, Coutinho OP, Reis RL. Bone tissue engineering: state of the art and future trends. Macromol Biosci. 2004;4:743-65.

4. Sommerfeldt DW, Rubin CT. Biology of bone and how it orchestrates the form and function of the skeleton. Eur Spine J. 2001;10:S86.

5. Zhu WM, Wang DP, Xiong JY. Biological characteristics and clinical application of scaffold materials for bone tissue engineering. J Clin Rehab Tissue Eng Res. 2007;48:23-6.

6. Meirelles L, Arvidsson A, Andersson M, Kjellin P, Albrektsson T, Wennerberg A. Nano hydroxyapatite structures influence early bone formation. J Biomed Mater Res. 2008;87(A):99-307.

7. Geesink RG, Hoefnagels NH. Six-year results of hydroxyapatitecoated total hip replacement. J Bone Joint Surg Br. 1995;77:534-47.

8. Liao SS, Cui FZ. In vitro and in vivo degradation of mineralized collagen-based composite scaffold: nanohydroxyapatite/collagen/ poly(L-lactide). Tissue Eng. 2004;10(1-2):73-80.

9. Williamson SL, Seibert JJ, Glasier CM, Leithiser RE, Aronson J. Ultrasound in advanced pediatric osteomyelitis. Pediatric Radiol. 1991;21:288-90.

10. Hamanishi C, Yosii T, Tanaka S. Maturation of the distracted callus. Sonographic observations in rabbits applied to patients. Acta Orthop Scand. 1994;65:335-8.

11. Tikku AP, Kumar S, Loomba K, Chandra A, Verma P, Aggarwal R. Use of ultrasound, color Doppler imaging and radiography to monitor periapical healing after endodontic surgery. J Oral Sci. 2010;52(3):411-6.

12. Craig JG, Jacobson JA, Moed BR. Ultrasound of fracture and bone healing. Radiol Clin North Am. 1999;37:737-51. 
13. Nandi SK, Kundu B, Ghosh SK, Kumar De D, Basu D. Efficacy of nano-hydroxyapatite prepared by an aqueous solution combustion technique in healing bone defects of goat. J Vet Sci. 2008;9(2):18391.

14. Zhu W, Xiao J, Wang D, Liu J, Xiong J, Liu L, Zhang X, Zeng Y. Experimental study of nano-HA artificial bone with different pore sizes for repairing the radial defect. Int Orthop. 2009;33(2):567-71.

15. Protopappas VC, Vavva MG, Fotiadis DI, Malizos KN. Efficacy of nano-hydroxyapatite prepared by an aqueous solution combustion technique in healing bone defects of goat. J Vet Sci. 2008;9(2):18391.

\section{Acknowledgments}

We would like to thank to the Faculty of Specialized Veterinary Sciences research council. Science and Research Branch of Islamic Azad University, hesarak, Tehran, for approval and financial support to finish this project.

\section{Correspondence:}

Rasoul Rahimzadeh

Department of Clinical Sciences, Faculty of Veterinary Medicine Sanandaj Branch, Islamic Azad University, Sanandaj, Iran drtwor@gmail.com

Received: September 20, 2011

Review: November 22, 2011

Accepted: December 19, 2011

Conflict of interest: none

Financial source: Sanandaj Branch, Islamic Azad University

${ }^{1}$ Research performed at Department of Clinical Sciences, Faculty of Veterinary Medicine, Sanandaj Branch, Islamic Azad University, Sanandaj, Iran 